\title{
An Investigation of Writing Strategies Used by the Students on the Perspective Language Proficiency and Gender
}

\author{
Suci Maharani*; Endang Fauziati; Slamet Supriyadi \\ Universitas Sebelas Maret, Indonesia \\ Email: sucimhrnii@gmail.com
}

http://dx.doi.org/10.18415/ijmmu.v5i5.364

\begin{abstract}
This study was aimed at describing the types of writing strategy used by students on the perspective language proficiency and gender, and the factors underlying the choice of writing strategies of the students at English department in one of university in Indonesia. This research was a qualitative study. The subject of the study was fourth students at English department on the undergraduate program which grouped into male, female, poor writing, and good writing. The methods of collecting data were observation, interview, and questionnaire. Based on the research finding, the type of writing strategies used by the students on the perspective language proficiency and gender covered the six strategies proposed by Oxford, namely: memory, cognitive, compensation, metacognitive, affective, and social strategy. The dominant writing strategy used by male students was memory strategy, whereas the female students was metacognitive strategy. And the dominant writing strategy used by the students having poor writing production was compensation strategy, whereas the students having good writing production was metacognitive strategy. Moreover, the factors underlying the choice of writing strategies used by male students were purpose of learning language, motivation, degree of awareness, learning style, and belief, whereas the factors underlying the choice of writing strategies used by female students were purpose of learning language, motivation, degree of awareness, learning style, belief, and learning environment. And the factors underlying the choice of writing strategies used by the students having poor writing were degree of awareness, belief, and proficiency, whereas the factors underlying the choice of writing strategies used by students having good writing were purpose of learning language, motivation, degree of awareness, and learning style.
\end{abstract}

Keywords: Gender; Language Proficiency; Oxford Taxonomy; Writing Strategies

\section{Introduction}

Writing is kind of integrative skill as well as an important, constructive, and complex process. It is an essential skill in foreign language learning to give the learners the opportunity in developing the proficiency which they need to write such as personal letters, essays, research papers, journal, and so on. Abu Jalil (cited in Al Gomoul., 2011, p. 1) stated that writing skills enhance cognitive and linguistic awareness. In producing good writing, the learners need to be taught writing skill in early ages of their education in order to give them provisions before they continue to the higher levels of education. 
In university level, students who learn in English department having a good writing skill are more important if it is compared with the other departments. There are some factors influencing the writing ability. Angelova (cited in Maftoon and Seyyedrezaei., 2012, p. 1598) mentioned some features which influence a good writing, they are, language proficiency, writing competence, the use of cohesive device, metacognitive knowledge about the writing task, writing strategies, and writers' personal characteristics. Asmari (2013, p. 130) also claimed that the factors which influence the writing is writing strategies. So it can be said that writing strategies influence the learners' writing where it is used during writing process.

According to Brown (2001, p. 335), writing is simply graphic representation of spoken language and that written performance is like oral performance, the difference only lying in graphic instead of auditory signals. Ur (1991, p. 162) also stated that writing is a means, as an end, or both as means and an end. Moreover, writing as a mean is simply used either as a means of getting the learners to attend and to practice a particular language point, or as a convenient method of testing it: providing information as to how well something has been learned in a form which the teacher can check their work. In the other hand, writing as an end means that the main writing objective is the writing itself. At the micro level, the students practice specific written forms at the level of word or sentence, whereas at the macro level, the emphasis is on content and organization. While, writing as both means and end is combining purposeful and original writing with the learning or practice of some other skill or content.

Based on Oshima and Hogue (2005, p. 5-6), Writing is a recursive process, that means the learners revise throughout the process, then moving back and forth among the stages. And Mayers (2005, p. 2) claimed that writing is an action-a process of discovering and organizing ideas, putting them on paper, and reshaping as well as revising them. Moreover, Gaith (cited in Dhakal., 2010, p. 8) also defined the term of writing as a complex process that allows the writers to explore thoughts and ideas and make them visible and concrete. Grabe and Kaplan (1996, p. 6) stated that writing is a technology, a set of skills which must be practices and learned through experience. Whereas Hadley (1993, p. 291) said that writing is a continuum of activities which range from the mechanical or formal aspects of writing down on the one end to the more complex act of composing on the order.

From some definitions above it can be concluded that writing is a complex process that yields a product which allows the writers to discover and organize ideas, put them on paper, reshape as well as revise them by using graphic symbols which has purpose and arrange based on particular rules.

Furthermore, several studies have been conducted on the field of writing strategies which focus on the students' proficiency and gende. For example, Lim et al. (2011) whose research focused on examining the writing strategies of Malaysian ESL undergraduate engineering learners. The findings of this previous study revealed that the two groups of students shared common writing strategies mainly cognitive strategies to generate ideas for their essay. Metacognitive and social strategies were also used to aid in generating ideas and searching for correct words or expressions. The strategies were used in combination and in a recursive manner to attain certain goals in their writing. It was also found that the difference in the strategy used between the two groups of good and weak students lied in the amount of strategies being used, reason for the use and how the students regulated the strategies to solve problems concerning the writing task.

Another research about writing strategies was also carried out by Penuelaz (2012). In her research, she used quantitative study to find out the writing strategies used by the students and to find out factor influencing the choice of their strategies. The results of this research revealed that proficient and less proficient writers used a wide variety of strategies; however, expert writers favored the use of cognitive, metacognitive, and compensation strategies, followed by affective, memory, and social strategies. The established relationships between the frequencies of strategy used and grade in English by 
means of ANOVA showed that the writers who got the best grades used more strategies. It also revealed that women also used more strategies than men in terms of both categories and individual strategies.

In addition, the other research taking writing strategies as its primary issue was also undertaken by Sadi and Othman (2012). In their research, they also examined the writing strategies of Iranian EFL Undergraduate Learners. From this study, it revealed that despite employing the strategies in combination and in a recursive fashion by both groups, two groups of writers were found to be different in their planning, drafting, and reviewing. Specifically, good and poor writers were found to be different in employing certain strategies like rereading, repetition, L1 use and rehearsing.

Furthermore, there was a research that also focused on writing strategies conducted by Mastan et al. (2017). They formulated two research objectives. The first research objective was to find out the types of writing strategies employed by ESL learners of intermediate proficiency level. And the second research objective was to explore the effects of writing strategy instruction on ESL learners' writing performance. The results of this research showed that the strategy instruction group had outperformed the control group with a statistically significant increase in scores from pretest to post test.

\section{Methodology}

This research is a qualitative study. This study is aimed at describing the types of writing strategy used by male and female students, types of writing strategy used by students having poor and good writing production, and the factors underlying the choice of writing strategies of the students. Twelve students at English department in one of university in Indonesia were involved as a sample in this research. The sample consisted of 3 males, 3 females, 3 poors, and three goods at English department on undergraduate program.

The researchers used observation, interview, and questionnaire in collecting the data. Observation, interview, and questionnaire are used to know the students' writing strategy. Interview is also used to know the factors underlying the choice of writing strategies used by the students. Furthermore, the researchers analyzed the data based on Oxford theory. The analysis of the data was done by adopting the interactive model by Miles and Huberman (1994) in the following steps: collecting the data from twelve participants, classifying the data, selecting/displaying the data to make it easier in analyzing and interpreting the data which is involved interpretation or meaning of the data.

\section{Results and Discussion}

This study revealed that from the six strategies proposed by Oxford, the male students used memory strategy as dominant strategy. It can be seen from Table 1 that memory strategy had the highest points of strategy rather than other strategies. Male students used memory strategy in high frequency usage, and other strategies used by them were in medium frequency. So, it can be concluded that dominant writing strategy used by male students was memory strategy.

Female students used all writing strategies proposed by Oxford. Although they used all strategies, there was dominant strategy employed by female students. It can be seen from Table 1 that female students used metacognitive, affective, and social strategy in high frequency, and other strategies were used in medium frequency. Although female students used metacognitive, affective, and social strategy in high frequency, they used metacognitive more often than others. So, it can be concluded that the dominant strategy employed by female students was metacognitive strategy. 
Table 1 The writing strategies used by male and female students

\begin{tabular}{llllllll}
\hline \multicolumn{7}{c}{ Strategy } \\
\hline & Memory & Cognitive & Compensation & Metacognitive & Affective & Social & Male \\
Mean & 3.58 & 3.13 & 2.83 & 3.37 & 2.94 & 3.38 & Students \\
\hline Strategy & & & & & & \\
\hline \multicolumn{2}{c}{ Memory } & Cognitive & Compensation & Metacognitive & Affective & Social & Female \\
\cline { 2 - 5 } Mean & 3.33 & 2.85 & 3.37 & 3.89 & 3.63 & 3.66 & Students \\
\hline
\end{tabular}

This study also revealed that from the six strategies proposed by Oxford, the students with poor writing production used compensation strategy as dominant strategy. It can be seen from Table 2 that compensation strategy has the highest points of frequency usage rather than other strategies. The poor writers used compensation strategy with 3.45 points of frequency usage, whereas other strategies are less than 3.45 points. So, it can be concluded that dominant writing strategy used by students having poor writing production was compensation strategy.

Students having good writing production used all writing strategies proposed by Oxford. Although they used all strategies, there is dominant strategy employed by good writers. It can be seen from Table 2 that students with good writing used compensation strategy, metacognitive strategy, and affective strategy in high frequency, and others were used in medium frequency. Although students with good writing used compensation, metacognitive, and affective strategy in high frequency, they used metacognitive more often than others. In conclusion, the dominant strategy employed by students having good writing production was metacognitive strategy.

Table 2 The writing strategies used by students having poor and good writing production

\begin{tabular}{llllllll}
\hline \multicolumn{7}{c}{ Strategy } \\
\hline & Memory & Cognitive & Compensation & Metacognitive & Affective & Social & Poor \\
Mean & 3.08 & 3.15 & 3.45 & 3.42 & 3.11 & 3.11 & Students \\
\hline Strategy & & & & & & \\
\hline \multicolumn{2}{c}{ Memory } & Cognitive & Compensation & Metacognitive & Affective & Social & Good \\
\cline { 1 - 4 } Mean & 3.25 & 3.28 & 3.79 & 4.09 & 3.72 & 2.94 & Students \\
\hline
\end{tabular}

On the other hand, based on the research deals with the factors underlying the choice of writing strategy by students, the researchers found out some fact. Both students on the perspective gender and proficiency have employed such kinds of writing strategies because of several factors. The factors underlying the choice of strategies by male and female students were almost similar. The male students used such kinds of strategies because of purpose of writing, motivation, degree of awareness, learning style and belief, whereas the female students used kinds of strategies because of purpose of writing, motivation, degree of awareness, learning style, belief, and learning environment. Moreover, the factors underlying the choice of the strategies by students having poor and good writing were also almost the same. The poor students used such kinds of strategies because of degree of awareness, belief, and proficiency, whereas the good students used such kinds of strategies because of purpose of writing, motivation, degree of awareness, and learning style.

According to Oxford (1990), she proposed many factors influencing the choice of strategies, those are degree of awareness, stage of learning, task requirements, teacher expectation, age, sex, nationality or ethnicity, learning style, personality traits, motivation, and the purpose of learning. Furthermore, based on Nambiar (2009), there are some factors which influence the choice of strategies, namely proficiency, learning environment, ethnicity, age, gender, learning style, motivation, and beliefs. 
Based on the analysis, the result shows that the students both on the perspective language proficiency and gender choose some kinds of writing strategies because of some factors mentioned above. There are many factors which can underlie the choice of writing strategy, but there are only some factors underlying the choice of writing strategies by the students.

With respect to the proficiency and motivation, in the finding of recent study, those are some factors underlying the choice of writing strategy by the students. It is in line with the finding from Elshawish's work (2012) which showed that the factor underlying choice of strategies are influenced by proficiency, motivation, and learning experience. The factors to the choice of writing strategies by the students on the perspective language proficiency and gender were almost similar.

\section{Conclusion}

Writing strategies are important in the process of writing, namely memory strategy, cognitive strategy, compensation strategy, metacognitive strategy, affective strategy, and social strategy. Those can influence the learners' writing result. The students chose the particular writing strategies because of several factors. The factors underlying the choice of writing strategies depend on the condition of the students themselves. Based on the findings of the research, the factors underlying the choice of writing strategies by students on the perspective language proficiency and gender difference are almost the same, so it depends on the strategy which is chosen by the students.

\section{References}

Al Gomoul, Mohammad Dayij Sulaeman. (2011). Students and Investigating Teachers' and Students' Attitudes Towards Writing Practice. Teaching and Assessing Writing Strategies for Secondary School: Journals. Int J Edu Sci, 3(1): 25-36.

Angelova, M. (1999). An Exploratory Study of Factors Affecting the Process and Product of Writing in English as a Foreign Language. Unpublished PhD dissertation, State University of New York, Buffalo.

Asmari. A. A. (2013). Investigation of Writing Strategies, Writing Apprehension, and Writing Achievement among Saudi EFL-Major Students. Canadian Center of Science and Education, 6(11): 130-143.

Brown, H. D. (2001). Teaching Principles: An Interractive Approach to Language Pedagogy. Second Edition. San Francisco: San Francisco State University.

Brown, Douglas. (2004). Language Assessment: Principles and Classroom Practice. San Fransisco State: Longman.

Maftoon, Parviz \& Seyyedreazaei, S. H. (2012). Good Language Learner: A Case Study of Writing Strategies. Theory and Practice in Language Studies, 2(8): 1597-1602.

Ur, Penny. (1996). A Course on Language Teaching. Cambridge: Cambridge University Press.

Oshima, A., \& Hogue, A. (2006). Writing Academic English. New York: Longman.

Mayers, A. (2005). Gateway to Academic Writing: Effective Sentence, Paragraph, and Essay. USA: Longman. 
Dhakal, Rebat Kumar. (2010). Student Motivation towards Creative Writing. Lalitpur: Internet Version.

Grabe and Kaplan. (1996). Theory and Practice of Writing. New York: Wesley longman Limited.

Hadley, A. O. (2001). Teaching Language in Context. London: Thomson Learning.

Penuelaz, A. B. C. (2012). The Writing Strategies of American Universty Students: Focusing an Memory, Compensation, Social, and Affective Strategies. Estudios de linguistica ingelisa aplicada, 77-113.

Sadi, F. F., \& Othman, J. (2012). An Investigation into writing Strategies of Iranian EFL Undergraduate Learners. World Applied Sciences Journal, 18(8): 1148-1157.

Oxford, Rebecca. (1993). Research on Second Language Learning Strategies, Anual Review of Applied Linguistic, 13: 175-187.

Oxford, Rebecca. (1990). Language Learning Strategies: What Every Teacher Should Know. New York: Newbury House Publishers.

Miles, M. B., \& Huberman, A. M. (1994). Qualitative Data Analysis. California: Sage publication inc.

Mastan, et al. (2017). The Effect of Writing Strategy Instruction pn ESL Intermediate Proficiency Learners' Writing Performance. Journal of Education Research and Review, 5(5): 71-78.

\section{Copyrights}

Copyright for this article is retained by the author(s), with first publication rights granted to the journal.

This is an open-access article distributed under the terms and conditions of the Creative Commons Attribution license (http://creativecommons.org/licenses/by/4.0/). 